\title{
Toxicity of malathion and its effect on the activity of acetylcholinesterase in various tissues of the grass carp, CtenOPharyngodon idella Val.
}

\author{
Salwa M. Abou El Ella \\ Researcher in Channel Maintenance Research Institute, National Water Research \\ Center, Delta Barrage, P.O. Box 13621, Egypt.
}

\begin{abstract}
$\mathrm{M}$ alathion, a widely used insecticide, is known to cause serious metabolic disturbance in non- target organisms, like fish. Bioassay tests were conducted on the grass carp fish to evaluate the acute toxicity of malathion by determining their LC50 after 24, 48, 72 and $96 \mathrm{~h}$ exposure. The safe concentration of this biocide was calculated on the basis of LC50 for 96h. The fish showed characteristic changes in behavior when exposed to various concentrations of malathion with difficulty in respiration, convulsions and short erratic jerky body actions. The sublethal toxic potency of malathion was indicated by inhibiting acetyl cholinesterase activity in the brain, muscle, gill and liver tissues of the grass carp. The changes in acetyl cholinesterase activity in the above tissues were decreased significantly up to 96h. Maximal inhibition of the enzyme was observed at 24 and $48 \mathrm{~h}$ intervals. So, by acquiring knowledge of LC50 values of a toxicant, its discharge into nearby water resources may be regulated to protect aquatic life.
\end{abstract}

Key words: Malathion, toxicity, Grass carp, acetyl cholinesterase.

\section{INTRODUCTION}

OrganOPhosphorus (OP) compounds are widely used in agriculture, medicine and industry. OP pesticides, in addition to their intended effects like the control of insects or other pests, are sometimes found to affect non- target organisms including humans (Chantelli- Forti et al., 1993; Chaudhuri et al.,1999). Exposure to OPs is also cause of longer- term damage to the nervous system, with reports of poor mental health and deficits in memory and concentration (Davis, 1991; Mason, 2000; Nigg and Knaak, 2000). Because of the serious environmental problems resulting from the use of pesticides in the agricultural sector, several countries are seeking to employ biological and other nonpolluting methods for combating pests.

Malathion is one of the most widely used organOPhosphate insecticides throughout the world. It is used to control pests affecting agricultural crOPs, ornamentals, green houses, livestock, stored grain, forests, buildings, households and gardens. Contributing to its pOPularity is its relatively low acute 
mammalian toxicity (Brenner, 1992; Hazarika et al., 2003). However, like other pesticides that have been found to cause irreparable damage to humans and the environment (Brenner,1992). They also cause serious metabolic disturbances in non- target species, like fish and freshwater mussels (U.S.E. prot. Agen. 1972).

Malathion contains potent neurotoxic molecules that exert their toxicity by blocking the breakdown of acetylcholine by the enzyme acetylcholinesterase (AchE). Acetylcholine is the primary neurotransmitter in the sensory and neuromuscular systems in most species. The activity of this system is vital to normal behavior and muscular function and represents a prime target on which some toxicants can exert a detrimental effect. Inhibition of the Ach E enzyme results in a build up of acetylcholine, causing a continuous and excessive stimulation of the nerve/ muscle fibres, which leads to tetany, paralysis and eventual death.

Measurement of AchE inhibition in aquatic organisms has already been used as a biomarker of neurotoxic contaminants (Habig and Di Giulo, 1988 ; Galgani et al., 1992 ; Payne et al., 1996 ; Mc Henery et al., 1997 ; Kirby et al., 2000 ; Sole` et al., 2000; Abdel- Halim et al.,2006).

The present investigation was undertaken to determine the followings:

1. The lethal level of malathion to the grass carp (CtenOPharyngodon idella Val.) and its safe levels that recommended for employment near water resources.

2. The effect of malathion on the activity of acetylcholinesterase in the grass carp.

\section{MATERIALS AND METHODS}

Specimens of the grass carp (wt. $30 \pm 5 \mathrm{gm}$ ) were obtained from Delta Breeding Station (DBS), Cairo. The fish were acclimatized in the laboratory aquaria for 2 weeks before being subjected to bioassay tests.

Technical grade malathion of 95\% purity was obtained from pesticides market. The fish were exposed to different concentrations of malathion. Ten specimens of grass carp species were exposed to each concentration. Mortality was observed at $24 \mathrm{~h}$ intervals for $96 \mathrm{~h}$. Fish were considered dead when they did not respond to probing with a glass rod. Dead specimens were removed immediately since dead organic material in static bioassays may deplete the DO, affecting tolerance limits of other specimens in bioassay tests (Schreck and Brouda, 1975), while safe concentrations were computed on the basis of LC50 for $96 \mathrm{~h}$, using application factors of 0.024 for organOPhosphate as mentioned by Bansal et al. (1980).

LC50 values of malathion for 24, 48, 72 and $69 \mathrm{~h}$ exposures were computed on the basis of probit analysis (Finney, 1964) as shown in Table (1). $1.0 \mathrm{mg} / \mathrm{l}$ from malathion was chosen to represent sublethal concentration, because the concentrations of malathion detected in the main stream of the River Nile in Cairo and at the beginning of each of Damietta, Rosetta branch as well 
as Ismailia canal lied in the ranges $0.1-2.0,1.0,1.0,0.21-3.6 \mathrm{mg} / \mathrm{l}$ respectively (Nile Basin Initiative, 2005). Acetylcholinesterase level was estimated beginning from $12 \mathrm{~h}$ to $96 \mathrm{~h}$, since there was no significant change in the values of controls at different periods,

Ten fish from aquaria and at the specified exposure time were anesthetized in $120 \mathrm{mg} / \mathrm{l}$ tricaine methanesulfonate (MS 222), solution. Immobilization was completed with in 20 seconds. Brain, muscle, gill and liver were removed for homogenization in cold 0.25M sucrose. Acetylcholinesterase activity was determined by the method of Metcalf (1951).

\section{Statistical analysis}

Studentst-test was employed to calculate the significance of the differences between control and experimental means. P values of 0.05 or less were considered statistically significant (Fisher, 1950).

\section{RESULTS AND DISCUSSION}

The data on LC50 values (Table 1) and the acute toxicity ranges at different time intervals reveal that acute toxicity of malathion ranged between $3.728 \mathrm{mg} / \mathrm{l}$ and $2.138 \mathrm{mg} / \mathrm{l}$ for grass carp. The safe concentrations of malathion was $0.0513 \mathrm{mg} / \mathrm{l}$ as shown in Table (1).

Table (1): Acute toxicity, confidence limit and safe concentration of malathion to the grass carp fingerlings.

\begin{tabular}{|c|c|c|c|c|c|}
\hline \multirow{3}{*}{ Fish species } & \multirow{3}{*}{ Biocide used } & \multicolumn{4}{|c|}{ Acute toxicity (LC50 values) and confidence limit (mg/I) } \\
\cline { 3 - 6 } & & $24 \mathrm{~h}$ & $48 \mathrm{~h}$ & $72 \mathrm{~h}$ & $96 \mathrm{~h}$ \\
\hline & & 3.728 & 2.838 & 2.444 & 2.138 \\
& & $(2.383-5.831)$ & $(1.709-4.711)$ & $(1.684-3.548)$ & $(1.459-3.134)$ \\
\cline { 3 - 5 } Grass carp & \multirow{3}{*}{ Malathion } & \multicolumn{4}{|c|}{ Safe concentration (mg/l) of malathion on the basis of 96hLC50 } \\
\cline { 3 - 5 } & & \multicolumn{4}{|c}{0.0513} \\
\cline { 3 - 5 } & & & \multicolumn{4}{|c}{} \\
\cline { 3 - 5 } & & &
\end{tabular}

The fish showed characteristic changes in behavior when exposed to various concentrations of malathion. Difficulty in respiration, convulsions and short erratic jerky body actions were observed. The skin of exposed specimens became light in color and secreted an excessive amount of mucus. Some specimens frequently dashed against the wall of the experimental aquaria. Subsequently, the fish became progressively lethargic. They lost their sense of equilibrium and had fast jerky body movements. The fish settled at the bottom before death. In low concentration of malathion, the responses were of a lesser degree. Control fish behaved normally. Similar observations have been made in different fish species following exposure to various biocides (Verma et al., 1978; Verma et al., 1980; Singh et al., 1981; Singh et al., 1984; Sanjay et al., 2005). 
The intense OPercular movements in the grass carp following exposure to malathion may be due to hypoxic stress accompanied by a sub sequential inhibitory influence of this compound on the respiratory mechanism. Reddy and Gomathy (1977) and Verma et al. (1979) have demonstrated that toxicity of organic biocides to fish involved a modification of gas exchange process at the gills with subsequent hypoxia at tissue level.

Mount and Stephan (1967) have suggested that the safe level of malathion for fishes lies somewhere between 1/15 and 1/45 of the 96h LC50 concentration. Their studies suggest that levels of malathion at or below 1/45 of the 96h LC50 will not harm the growth or reproduction of the fathead minow (Pimephales promelas), and they suggested the same application of this level for use on other fish species. For the grass carp, this would mean that at a level of malathion greater than $0.0513 \mathrm{mg} / \mathrm{l}$, damage to the fish's well-being could possibly occur.

The changes in acetylcholinesterase activity in the brain, muscle, gill and liver tissues of malathion exposed fishes decreased significantly up to $72 \mathrm{~h}$. Maximal inhibition of the enzyme was observed at 24 and $48 \mathrm{~h}$ intervals (Table 2).

Table (2): Acetylcholinesterase (AchE) activity ( $\mu \mathrm{mol} / \mathrm{mg}$ protein $/ \mathrm{h}$ ) in various tissues in normal and malathion exposed fish at different hours of exposure.

\begin{tabular}{|c|c|c|c|c|c|c|c|}
\hline \multicolumn{8}{|c|}{ Activity of AchE ( $\mu \mathrm{mol} / \mathrm{mg}$ protein $/ \mathrm{h})$} \\
\hline \multirow{2}{*}{ Tissue } & \multirow{2}{*}{ control } & \multicolumn{6}{|c|}{ Hours of malathion exposure } \\
\hline & & & 12 & 24 & 48 & 72 & 96 \\
\hline \multirow[t]{3}{*}{ Brain } & 26.35 & $\mathrm{M}$ & 24.083 & 20.55 & 15.033 & 18.6 & 24.717 \\
\hline & \pm 0.812 & S.D. & \pm 1.078 & \pm 0.873 & \pm 0.864 & \pm 0.616 & \pm 0.685 \\
\hline & & $\mathrm{P}$ & $\mathrm{P}<0.01$ & $\mathrm{P}<0.01$ & $\mathrm{P}<0.01$ & $\mathrm{P}<0.01$ & $\mathrm{P}<0.01$ \\
\hline \multirow[t]{3}{*}{ Muscle } & 17.483 & $\mathrm{M}$ & 15.233 & 11.233 & 8.899 & 13.666 & 16.883 \\
\hline & \pm 0.614 & S.D. & \pm 0.606 & \pm 0.450 & \pm 0.289 & \pm 0.653 & \pm 0.402 \\
\hline & & $\mathrm{P}$ & $\mathrm{P}<0.01$ & $\mathrm{P}<0.01$ & $\mathrm{P}<0.01$ & $\mathrm{P}<0.01$ & N.S. \\
\hline \multirow[t]{3}{*}{ Gill } & 11.483 & $\mathrm{M}$ & 9.567 & 8.217 & 6.25 & 7.183 & 9.433 \\
\hline & \pm 0.531 & S.D. & \pm 0.476 & \pm 0.366 & \pm 0.327 & \pm 0.232 & \pm 0.484 \\
\hline & & $\mathrm{P}$ & $\mathrm{P}<0.01$ & $\mathrm{P}<0.01$ & $\mathrm{P}<0.01$ & $\mathrm{P}<0.01$ & $\mathrm{P}<0.01$ \\
\hline \multirow[t]{3}{*}{ Liver } & 5.55 & $\mathrm{M}$ & 3.55 & 2.083 & 1.233 & 2.633 & 4.083 \\
\hline & \pm 0.451 & S.D. & \pm 0.414 & \pm 0.293 & \pm 0.294 & \pm 0.301 & \pm 0.147 \\
\hline & & $\mathrm{P}$ & $\mathrm{P}<0.01$ & $\mathrm{P}<0.01$ & $\mathrm{P}<0.01$ & $\mathrm{P}<0.01$ & $\mathrm{P}<0.01$ \\
\hline
\end{tabular}

Each value is the mean \pm S.D. , $\mathrm{P}=\mathrm{t}^{\prime}$ test , N.S. = Not significant.

Since the inhibition of acetylcholinesterase activity gradually increased from 12 to 24 and $48 \mathrm{~h}$ and decreased from $48 \mathrm{~h}$ to $96 \mathrm{~h}$ (Table 2), it can be suggested that inhibition of the esterase by malathion is dependent on the 
duration of exposure. After 96h of exposure, the enzyme activity in all the tested tissues as compared to that in normal tissue, thus indicating the reversal of inhibition in treated fishes. It is likely that the effect of malathion decreases after $48 \mathrm{~h}$ probably due to its degradation.

The differential inhibition (descending order) of acetyl cholinesterase activity in the four tested tissues (brain> muscle> gill>liver) may be due to the presence of isozymes with different affinities for the substrate and the inhibitor. Further, the pesticide itself may be present in different amounts in the different tissues, producing differential inhibition or the inhibitor may be metabolized at different rates. This assumption has been described by a number of authors as Wilson (1967) and Kabeer Ahammad et al. (1980).

In conclusion, by acquiring knowledge of LC50 values of a toxicant, its discharge into nearby water resources should be regulated to protect aquatic life. The safe concentration determined in the present investigation is actually fractions of LC50 values and therefore, would be useful in regulating their discharges.

\section{REFERENCES}

Abdel-Halim, K.Y. ; Salama, A.K. ; El-khateeb, E.N. and N.M. Bakry (2006).OrganOPhosphorus pollutants (OPP) in aquatic environment at Damietta Governorate, Egypt: Implications for monitoring and biomarker responses. Chemosphere, 63(9):1491-1498.

Bansal, S.K.; Verma, S.R.; Gupta, A.K. and Daleta, R.C. (1980). Predicting long term toxicity of subacute screening of pesticides with larvae and early juveniles of four species of freshwater major carps, J. Ecotoxicol. Environ .Saf., 4:224- 231.

Brenner, L. (1992). Malathion Fact sheet. Journal of pesticide Reform. Northwest Coalition for Alternatives to pesticides, Eugene, OR. 12:1-17.

Chantelli-Forti , G.; Paolini, M. and Hrelia, P. (1993). Multiple end point procedure to evaluate risk from pesticides. Environ Health perspect, 101:15-20.

Chaudhuri, K.; Selvaraj, S. and Pal, A. K. (1999). Studies on the genotoxicity of endosulfan in bacterial systems. Mutat., Res. 439:63-67. 
Davis, J. E. (1991). Neurotoxic concerns of human pesticide exposures, Am. J. Int. Med.,18:327-331.

Finney, D. J. (1964). Probit analysis, 2edition (Cambridge, University press).

Fisher, R. A. (1950). Statistical methods for research workers. 11 th edition. Oliver and Boyed, London, 75 pp.

Galgani, F.; Bocquene, G. and Cadiou, Y. (1992). Evidence of variation in cholinesterase activity in fish along a pollution gradient in the North Sea. Mar. Ecol. Progr. Ser., 91: 77-82.

Habig, C. and Di Giulio, R.T. (1988). The anticholinesterase effects of the cotton defoliant S,S,S- Tri-n-Butyl phosphorotrithioate (DEF) on channel cat fish . Mar. Environ. Res., 24: 193-197.

Hazzarika, A.; Sarkar, S.N.; Hajare, S.; Kataria, M. and Malik, M.K. (2003). Influence of malathion pretreatment on the toxicity of anilofos in male rats: a biochemical interaction study. Toxicology. , 185:1-8.

Kabeer Ahmmed, S.I.; Sailatha, D. and Ramana, K.K. (1980). Impact of malathion on acetylcholinesterase in the tissues of the fish Tilapia mossambica (Peters). J. Biosci., 2(1): 37-41.

Kirby, M.F.; Morris, S.; Hurst, M.; Kirby, S.J.; Neall, P.; Tylor, T. and Fagg, A., (2000).The use of cholinesterase activity in flounder (Platichthys flesus) muscle tissue as a biomarker of neurotoxic contamination in UK estuaries. Mar. Poll. Bull., 40:780-791.

Mason, H.J. (2000). The recovery of plasma cholinesterase and erythrocyte acetylcholinesterase activity in workers after over- exposure to dichlorvos. Occup. Med (Lond.)., 50:343 -347.

Mc Henery, J .G.; Linley-Adams, G. E.; Moore, D. C.; Rodger, G.K. and Davies, I. M. (1997). Experimental Field studies of effects of dichlorvos exposure on acetylcholinesterase activity in the gills of the mussel, Mytilus edulis L. Aquat . Toxical., 38:125-143.

Metcalf, R.L. (1951). In Methods in biochemical analysis, ed .D. Glick (New York : Interscience), 5.

Mount, D.I, and Brungs. W.A. (1967).A simplified dosing apparatus for fish toxicological studies. Water Res., 1(1):21. 
Nigg, H.N. and Knaak, J. B. (2000). Blood cholinesterases as human biomarkers of organOPhosphorus pesticide exposure. Rev. Environ. Contam. Toxicol., 163:11-29.

Nile Basin Initiative, 2005. Nile Basin National Water quality Monitoring Basin Study Report for Egypt. Nile Tran boundary Environmental Action Project.

Payne, J.; Mathieu, A.; Melvin, W. and Fancey, L.L. (1996). Acetylcholinesterase, an old biomarker with a new future? Field trials in association with two urban rivers and a paper mill in New found land .Mar. pollut. Bull., 32:225-231.

Reddy, P.G. and Gomathy, S. (1977). Toxicity and respiratory effects of pesticides, thiodan on catfish, Mystus vittatus, Indian J. Environ. Health, 19:360-363.

Ridgway, R.L.; Tinney, J.C.; Macgregor, J.T. and Slater, N.J. (1978). Pesticide use in agriculture. Environ Health Perspect., 27:103-112.

Sanjay Pandey, Ravindra Kumar, Shilpi Sharma, N.S. Nagpure, Satish K. Srivastava and M.S. Verma (2005). Acute toxicity bioassays of mercuric chloride and malathion on air-breathing fish Channa punctatus (Bloch), Ecotoxicology and Environmental Safety, 61(1): 114-120.

Schreck, C.B. and Brouda, P. (1975). Dissolved oxygen depletion in static bioassay systems. Bull. Environ . contam. Toxicol., 14:149-152.

Singh, D.N.; Tyagi, R.K. and Panwar, R.S. (1981). Toxicity of some organic biocides to a freshwater fish Cyprinus carpio communis (Linn.), J. Environ. Biol., 2:41-46.

Sole, M., Porte,C., Barcelo, D., Albaiges, G., (2000). Bivalves residue analysis for assessment of coastal pollution in the Ebro Delta (NW Mediterranean Sea). Mar. Poll. Bull., 40: 746 -753.

U.S.E. Protection Agency, (1972). The use of pesticides in suburban homes and gardens and their impact on the aquatic environment, Pesticide study series, No.2, Washington, D.C. 
Verma, S.R.; Bansal, S.K. and Dalela, R.C. (1978). Toxicological studies with selected organic pesticides to a freshwater teleost, Saccobranchus fossilis, and its application in controlling water pollution, Arch. Environ. Contam. Toxicol., 7:317-323.

Verma, S.R.; Bansal, S.K.; Gupta, A.K.; Pal, N.; Tyagi, A.K.; Bhatnagar , M.C.; Kumar, K. and Dalela. R.C., (1979). Acute toxicity of twenty three pesticides to a freshwater Saccobranchus fossilis Proc. Symp. Environ. Biol., pp.481- 497.

Verma, S.R; Rani, S.; Bansal, S.K. and Dalela, R.C. (1980). Effect of pesticides thiotax, dichlorvos and carbofuran on the test fish, Mystus vittatus. Water air Soil Pollut., 13:229-234.

Wilson, I.B. (1967). In drugs affecting peripheral nervous system, ed. A. Burger (New York: Dekker) 381 pp. 